\title{
Serotonin Transporter Promoter Polymorphism Genotype Is Associated With Behavioral Disinhibition and Negative Affect in Children of Alcoholics
}

\author{
Geoffrey R. Twitchell, Gregory L. Hanna, Edwin H. Cook, Scott F. Stoltenberg, Hiram E. Fitzgerald, and Robert A. Zucker
}

\begin{abstract}
Background: Serotonergic (5-HT) dysfunction has been implicated in the etiology of both behavioral disinhibition (BD) and negative affect (NA). This work extends our previous finding of relationships between whole blood 5-HT and both BD and NA in pubescent, but not prepubescent, children of alcoholics and continues examination of a hypothesized role of 5-HT dysfunction in alcoholism risk. The long and short (L and S) variants of the 5-HT transporter gene-linked polymorphic region (5-HTTLPR) are responsible for differing transcriptional efficiencies in 5-HT uptake. Although associations have been found between the SS 5-HTTLPR genotype and severe alcoholism and neuroticism, recent reports describe relationships between the LL genotype and both low level of response to alcohol and alcoholism diagnosis and a predominance of the LL genotype in early-onset alcoholics.

Methods: This report is from an ongoing prospective study of the development of risk for alcoholism and other problematic outcomes in a sample of families classified by father's alcoholism subtype. This study examines relationships between 5-HTTLPR genotype and both child BD (Child Behavior Checklist Aggressive Behavior) and NA (Child Behavior Checklist Anxious/Depressed) in offspring from 47 families.

Results: Results showed significantly higher levels of BD and NA in the 16 children with the LL genotype than the 46 SS or SL children.

Conclusions: Behaviors of undercontrol, which occur at increased rates in children of alcoholics, may be genetically influenced through the regulation of the 5-HT transporter. Due to the small sample size and the preliminary nature of our findings, replication is necessary.
\end{abstract}

Key Words: Serotonin Transporter, Behavioral Disinhibition, Negative Affect, Children of Alcoholics, Genetic.
$S^{1}$ EROTONERGIC (5-HT) DYSFUNCTION as measured by central and peripheral measures has been consistently implicated in both behavioral disinhibition (BD; impulsive aggression and type II alcoholism) and negative affect (NA; depression and anxiety) in clinical and nonpatient samples of adults and children (Brown and Linnoila, 1990; Coccaro et al., 1997; Fils-Aime et al., 1996; Johnson et al., 2000; Lesch et al., 1996; Linnoila et al., 1983;

From the Integrated Substance Abuse Programs (GRT), University of California, Los Angeles, California; the Department of Psychology, Michigan State University (GRT, HEF), East Lansing, Michigan; the Departments of Psychiatry and Psychology and the Alcohol Research Center, University of Michigan (GLH, SFS, RAZ), Ann Arbor, Michigan; and the Laboratory of Developmental Neuroscience, Department of Psychiatry, University of Chicago (EHC), Illinois.

Received for publication December 19, 2000; accepted May 1, 2001.

Supported by NIAAA Grants 2RO1 AA07065 (to RAZ and HEF) and K01 AA00295 (to SFS), a Biomedical Research Grant from Michigan State University, pilot fund support from the University of Michigan Alcohol Research Center, and a NIDA Postdoctoral Training Fellowship to UCLA ISAP (DA07272)

Reprint requests: Geoff R. Twitchell, PhD, UCLA Integrated Substance Abuse Programs, 1640 S. Sepulveda, Suite 200, Los Angeles, CA 90025; Fax: 310-267-2496; E-mail: twitche2@ucla.edu

Copyright (C) 2001 by the Research Society on Alcoholism.
Manuck et al., 1998; Nobile et al., 1999; Pfeffer et al., 1998; Sander et al., 1997; Stoff and Vitiello, 1996; Twitchell et al., 2000; Virkkunen et al., 1996). Many psychiatric genetic studies have suggested that a functional polymorphism in the regulatory region of the 5-HT transporter gene-linked polymorphic region (5-HTTLPR) may be a strong candidate gene for behavioral disorders such as alcoholism, anxiety, and depression (Greenberg et al., 2000; Hallikainen et al., 1999; Kaufman et al., 1998; Lesch et al., 1996; Lichtermann et al., 2000; Nobile et al., 1999; Sander et al., 1997; Schuckit et al., 1999; Turker et al., 1998), although some studies have produced negative results (Edenberg et al., 1998; Gelernter et al., 1998; Jorm et al., 1998; Ohara et al., 1998).

Although children of alcoholics (COAs) are at increased risk for behavioral and affective dysregulation (Sher, 1991, 1997), few studies have examined the potential role 5-HT may play in their development (Twitchell et al., 1998, 2000). Furthermore, to our knowledge, no study has examined associations between 5-HTTLPR genotype and both BD and NA, two characteristics that may place these children at risk for the development of alcoholism. Several studies have documented 5-HT dysfunction in men with positive family histories of alcoholism (LeMarquand et al., 1999; 
Rausch et al., 1991). Additionally, in a study of abstinent adult alcoholics and their adult and young children, increased 5-HT uptake was found in the alcoholics compared with controls, as well as in the alcoholics' young children (mean age, $11 \pm 1.1$ years), most of whom had not ever consumed alcohol, in comparison with age- and sexmatched control children (Ernouf et al., 1993).

Previously in our own study of COAs, we found lower whole blood 5-HT content in six children who exhibited overt behavior problems as measured by clinical range Child Behavior Checklist (CBCL; Achenbach, 1991) Total Behavior Problem scores in comparison with 38 children with CBCL Total Behavior Problem scores in the normal or borderline range (Twitchell et al., 1998). In a subsequent study of 62 children (original sample with the addition of 18 children) subtyped by paternal alcoholism classification, results indicated that puberty moderated relationships between 5-HT and both BD and NA, with relationships observed in pubescent, but not prepubescent, children (Twitchell et al., 2000).

\section{5-HTTLPR GENOTYPE IS RELATED TO FUNCTIONAL DIFFERENCES IN 5-HT UPTAKE}

It has been determined that the long and short ( $\mathrm{L}$ and $\mathrm{S}$ ) variants of the 5-HTTLPR are responsible for differing transcriptional efficiencies in 5-HT uptake, one component of 5-HT functioning (Cravchik and Goldman, 2000). The LL variant has been associated with three times greater 5-HT uptake in lymphocytes (Lesch et al., 1996) and blood platelets (Greenberg et al., 1999), in comparison to the SS or heterozygous SL variants. Consequently, the LL variant is expected to be related to increased 5-HT transporter number and function, reduced levels of intrasynaptic 5-HT, and reduced overall 5-HT function (Johnson, 2000). In a recent study with depressed children and adolescents which examined blood platelet measures of 5-HT function, control children with the LL genotype had greater initial 5-HT uptake than control children with SS or SL genotypes (Nobile et al., 1999).

5-HT transporter function in the brain has also been used as a model system for studying potential functional differences among 5-HTTLPR genotypes. In postmortem midbrain samples of ethanol users, 5-HT transporter binding and messenger RNA levels were found to vary by 5-HTTLPR genotype in patterns consistent with the previously reported pattern of the LL genotype being associated with higher function than SS or SL genotypes (Little et al., 1998). In vivo imaging of 5-HT transporter availability in alcoholics and healthy controls further supports functional differences between those with the LL genotype in comparison to those with either the SS or LS genotype, with an interaction observed between diagnosis and 5-HTTLPR genotype on 5-HT transporter availability (Heinz et al., 2000). Among controls, the LL genotype was related to an increase in 5-HT transporter availability in comparison to S carriers. Among alcoholics, the LL genotype was associated with reduced 5-HT transporter availability. However, in a recent study of major depression and suicide, no relationship was observed between the 5-HTTLPR genotype and level of 5-HT transporter binding in the prefrontal cortex (Mann et al., 2000).

\section{5-HTTLPR GENOTYPE AS A CANDIDATE GENE FOR NEGATIVE AFFECT AND BEHAVIORAL DISINHIBITION}

Numerous studies have followed the initial demonstration that the $\mathrm{S}$ allele is related to a trait associated with anxiety, hostility, and depression (Lesch et al., 1996), although many studies have failed to replicate this small effect size finding (Gelernter et al., 1998; Jorm et al., 1998; Ohara et al., 1998). The relationship between 5-HT dysfunction and impulsive aggression is also well documented (Linnoila et al., 1983; Virkkunen et al., 1989). That 5-HT dysfunction is implicated in several psychiatric disorders in which behavioral and affective dysregulation is a key component (e.g., obsessive-compulsive disorder, depression, and antisocial alcoholism) suggests that any factor that modulates 5-HT function may be considered an important candidate gene (Stoltenberg and Burmeister, 2000).

Data regarding the relationships between 5-HTTLPR genotype and alcoholism are complicated and often conflicting (Edenberg et al., 1998; Hallikainen et al., 1999; Hammoumi et al., 1999; Johnson et al., 2000; Jorm et al., 1998; Sander et al., 1998). Although a large candidate gene family-based association analysis found no association between 5-HTTLPR genotype and alcoholism diagnosis (Edenberg et al., 1998), recent results from another large candidate gene family-based association analysis provide support for allelic association of the 5-HTTLPR short variant with alcohol dependence (Lichtermann et al., 2000). These discrepancies may reflect the heterogeneity of the disorder, the complexity inherent in psychiatric genetic studies, or both of these. Given that alcoholism is a heterogeneous and polygenic disorder, it may be necessary to study subtypes separately. For example, type II, or antisocial, early-onset alcoholism (Cloninger et al., 1981), which frequently includes impulsive aggressive behavior, has been found to have a stronger genetic basis, perhaps due to the presence of impulsive aggression, a behavior that has been reliably associated with 5-HT dysfunction.

To follow up on our previous findings of relationships between a peripheral index of 5-HT function and behavior, this study was designed to examine 5-HTTLPR as a candidate gene for behavioral and affective dysregulation in COAs. Given the reported associations between 5-HTTLPR genotype and NA, low level of response to alcohol, and alcoholism, we predicted that relationships would be found between 5-HTTLPR genotype and both $\mathrm{BD}$ and NA. 
Table 1. Sampling Design

\begin{tabular}{|c|c|c|c|c|}
\hline \multirow{2}{*}{$\begin{array}{l}\text { Father's alcoholism } \\
\text { classification }\end{array}$} & \multicolumn{4}{|c|}{ Child 5-HTTLPR genotype } \\
\hline & $\mathrm{LL}(n=16)$ & $\mathrm{SL}(n=33)$ & $\mathrm{SS}(n=13)$ & SS/SL $(n=46)$ \\
\hline \multirow[t]{2}{*}{ Antisocial alcoholic $(n=17)$} & Sons $=4$ & Sons $=8$ & Sons $=4$ & Sons $=12$ \\
\hline & Daughters $=1$ & Daughters $=4$ & Daughters $=0$ & Daughters $=4$ \\
\hline \multirow[t]{2}{*}{ Nonantisocial alcoholic $(n=20)$} & Sons $=5$ & Sons $=12$ & Sons $=2$ & Sons $=14$ \\
\hline & Daughters $=2$ & Daughters $=2$ & Daughters $=3$ & Daughters $=5$ \\
\hline \multirow[t]{2}{*}{ Nonalcoholic control $(n=10)$} & Sons $=2$ & Sons $=5$ & Sons $=3$ & Sons $=8$ \\
\hline & Daughters $=2$ & Daughters $=2$ & Daughters $=1$ & Daughters $=3$ \\
\hline
\end{tabular}

\section{METHODS}

\section{Sample}

Subjects were 62 non-Hispanic white children without fetal alcohol syndrome between the ages of 7 and 16 years ( 45 boys, 17 girls; mean age, $10.9 \pm 2.0$ years) from a subsample consisting of 47 lower- to lowermiddle-class families drawn from the ongoing Michigan State UniversityUniversity of Michigan Longitudinal Study (Fitzgerald et al., 1995; Zucker, 1987; Zucker et al., 1996, 1997). The larger study from which this sample is drawn is observing a population-based sample of COAs, both biological parents, and demographically similar nonalcoholic control families at 3-year intervals, beginning when the male target children were ages 3 to 5 years and the female target children were between ages 3 and 11 years. Paternal alcoholism diagnosis was assessed with Feighner diagnostic criteria (Feighner et al., 1972) within a structured clinical interview format. Inclusion criteria for the larger study involved having a biological son between 3.0 and 5.0 years of age living in an intact family with both biological parents. Maternal alcoholism was neither inclusionary nor exclusionary, although a subset of the women married to antisocial alcoholic men $(41 \%)$ met a lifetime DSM-III-R alcohol abuse or dependence diagnosis.

Design for Alcoholism Subtyping. The sampling design for this study is presented in the left column of Table 1. Families were subtyped by paternal alcoholism and antisocial personality disorder diagnoses in earlier analytic work with the longitudinal study (cf Poon et al., 2000; Wong et al., 1999; antisocial alcoholism, nonantisocial alcoholism, nonalcoholic control). For this study, we deliberately selected families to achieve an approximately equal distribution across the three groups. Children were later categorized by 5 -HTTLPR genotype. Fifteen of the 47 families had both a son and a daughter in the appropriate age range; in these instances, both children were included.

5-HTTLPR Genotype. Genotyping methods have been described previously. Please see Hanna et al. (1998) for a full description of methods used here. There is some evidence for dominance of the S allele (Greenberg et al., 1999; Lesch et al., 1996). Consequently, SS and SL genotypes have frequently been combined. In our analyses we use this approach, which also has the benefit of increasing statistical power. In addition, we provide data for child behavioral measures for all three genotypes so that the data are more informative to other researchers.

\section{Assessing Child Behavioral Disinhibition and Negative Affect}

The 4- to 18-year-old version of the CBCL (Achenbach, 1991) was used to gather child behavioral data. The CBCL is the most commonly used questionnaire for clinical classification of child behavior problems in the United States. Maternal ratings obtained at the most recent wave of data collection were used. Test-retest reliability of item scores on the CBCL ranging from 0.95 at a 1 -week interval to 0.84 at a 3 -month interval and adequate construct validity have been demonstrated (Achenbach, 1991).

Child BD. The Aggressive Behavior scale from the CBCL was used as a behavioral phenotype indicator of BD (i.e., Argues a lot; Cruelty, bullying, or meanness to others; Gets in many fights; Screams a lot; Temper tantrums or hot temper; Threatens people).

Child NA. The CBCL Anxious/Depressed scale was used as a behavioral phenotype indicator of NA (i.e., Complains of loneliness; Cries a lot;
Nervous, highstrung or tense; Unhappy, sad or depressed; Too fearful or anxious).

\section{Evaluating Child Alcohol Consumption}

Children reported their alcohol use on a brief questionnaire that was administered privately and confidentially. Nine children (six boys, three girls) reported having consumed alcohol at some point in their lives $(15 \%)$. However, all of these children denied having consumed any alcohol within the past 4 weeks. Therefore, this sample is composed of children who have not yet begun regular drinking.

\section{Medication Screening}

At the time of blood draw, the primary caretaking parent (95\% mothers) completed a child health history that assessed child's height, weight, and the presence of any psychotropic medications taken within the past month.

\section{Demographic Variables}

Families were characterized by demographic questionnaire measures of socioeconomic status, parental years of education, family income, and child age. Parental socioeconomic status was coded with the Revised Duncan Socioeconomic Index (Duncan TSE12; Stevens and Featherman, 1981). Parental education was measured by the total years of academic or vocational education achieved (scores ranged from 9 to 20 years of education)

\section{Procedure}

Approval from the appropriate institutional review boards was obtained prior to study implementation. Medication screening and blood sampling were performed by GRT during an in-home session. Informed consent was obtained from all study participants before data collection. All subjects donated their blood samples and were paid for filling out the questionnaires.

Statistical Analysis

Group differences were tested with independent sample $t$-tests. All reported probabilities are two tailed.

\section{RESULTS}

The sociodemographic characteristics of the sample are shown in Table 2.

\section{5-HTTLPR Genotype is Related to Both Behavioral Disinhibition and Negative Affect in COAs}

The $t$-tests showed significantly higher levels of BD and NA in the 16 children with the LL genotype $(t=-2.35, d f$ $=60, p<0.05 ; t=-2.52, p<0.05$, respectively) than the 
Table 2. Sociodemographic Characteristics of Sample $(N=62)$

\begin{tabular}{lrr}
\hline \multicolumn{1}{c}{ Sociodemographics } & Mean & \multicolumn{1}{c}{ SD } \\
\hline Child age (yr) & 10.88 & 2.03 \\
Father's years of education & 14.03 & 2.52 \\
Mother's years of education $^{\text {Father's SES }}{ }^{a}$ & 13.47 & 2.24 \\
Mother's SES $^{\text {a }}$ & 37.61 & 21.25 \\
Family income (US \$) & 30.56 & 12.92 \\
\hline
\end{tabular}
tus.

$46 \mathrm{SS}$ or SL children. When analyses were re-run with COAs only, the pattern of results was the same.

The presence of 15 sibling pairs within the 47 families violates the assumption of independence. To address this issue, five different random samples were drawn such that only one child from each family was included. Four of these five samples yielded significant relationships for both BD and NA. For the remaining sample, the results were not significant, although the $p$ values were 0.10 and 0.07 for Aggressive Behavior and Anxious/Depressed, respectively.

Post hoc exploratory analyses evaluated the relationships between 5-HTTLPR genotype and the remaining nine CBCL scales and showed significant differences between LL and SS or SL genotypes for Internalizing, Social Problems, Externalizing, and Total Behavior Problems. The same pattern of findings emerged such that the LL genotype children exhibited higher means, indicating more problems on each CBCL scale (Table 3). The relationship between child 5-HTTLPR genotype and any child alcohol consumption was evaluated with $\chi^{2}$. Of the LL genotype children, $31.3 \%$ had consumed alcohol at some point in their lives. In comparison, only $8.7 \%$ of the SS or SL genotype children had consumed alcohol at any point in their lives. This relationship was significant $\left(\chi^{2}=4.87, d f=\right.$ $1, p<0.05)$.

\section{DISCUSSION}

The primary finding was that child 5-HTTLPR genotype was related to both $\mathrm{BD}$ and NA with the LL variant of the 5-HTTLPR genotype associated with increased levels of $\mathrm{BD}$ and NA. This finding lends support to the hypothesis that behavioral undercontrol found at increased rates in COAs may be genetically influenced through the regulation of the 5-HT transporter.

Our results are consistent with findings in the adult literature suggesting that 5-HT function plays a role in a spectrum of behaviors marked by undercontrol. Furthermore, the finding of a relationship between 5-HTTLPR genotype and $\mathrm{BD}$ in children at risk for later problems in behavioral and affective regulation is consistent with the accepted theory of 5-HT's role as a general inhibitor of motoric behaviors such as impulsive aggression. Similarly, our finding of a relationship between 5-HTTLPR genotype and NA is consistent with the more recent suggestion that 5-HT may also play a role in affective expression (Lesch et al., 1996; Lesch and Mossner, 1998; Lucki, 1998; Mazzanti et al., 1998).

Post hoc exploratory analyses provided further support for these conclusions. Independent sample $t$-tests on all CBCL scales revealed significant relationships between 5-HTTLPR genotype and 6 of the 11 CBCL scales, with relationships consistently observed in the areas of behavioral (Aggressive Behavior, Externalizing, Total Behavior Problems) and affective (Anxious/Depressed, Internalizing) dysregulation. A similar relationship was observed for child genotype and social functioning (Social Problems), providing further support for the direct and moderating effect of 5-HT on social behavior in both human (Knutson et al., 1998; Kruesi et al., 1990) and nonhuman (Higley et al., 1996; Mehlman et al., 1995; Raleigh et al., 1983, 1985) primates.

Furthermore, a $\chi^{2}$ analysis of child 5-HTTLPR genotype and alcohol consumption indicated that significantly more LL genotype than SS or SL genotype children reported that they had already consumed alcohol (i.e., they had a significantly earlier onset of alcohol use). Taken together, our findings of greater behavioral and affective dysregulation and higher rates of first-time alcohol consumption in children with the LL genotype of 5-HTTLPR provide additional support for the hypothesized role of 5-HT as a potential neurobiological substrate for alcohol-related risk factors and potential development of early-onset, antisocial alcoholism. The genotypic characterization of these children early in their lives documents important biological differences and supports observing these children for the occurrence of problem drinking or alcoholism in early adolescence and adulthood.

A limitation of this study was that it did not use a family-based approach (e.g., quantitative transmission/disequilibrium test; Abecasis et al., 2000). In addition, given the size of the study sample, the observed statistical power to detect differences between genotypes was low (i.e., less than $50 \%$; two-way $\alpha=0.05$ ) for the majority of the CBCL scales. Although the sample is composed of children from a relatively ethnically homogeneous group (non-Hispanic, white families), we cannot rule out population stratification (Pritchard et al., 2000). Consequently, these findings should be considered to be preliminary and interpreted with caution. Finally, although we report associations between the LL genotype of 5-HTTLPR and BD and NA, some studies have reported relationships between the SS genotype and neuroticism (Lesch et al., 1996), alcoholism risk (Lichtermann et al., 2000), and antisocial alcoholism (Hallikainen et al., 1999; Sander et al., 1998). It is important to note that our findings are consistent with those of Schuckit et al. (1999), who report a relationship between the LL genotype of 5-HTTLPR and both alcoholism risk as measured by low level of response to alcohol and subsequent alcoholism diagnosis and the recent finding of a predominance of the LL variant among early-onset alcoholics (Ishiguro et al., 1999; Johnson, 2000). 
Table 3. Child Behavioral Measures as a Function of 5-HTTLPR Genotype

\begin{tabular}{|c|c|c|c|c|c|c|c|c|c|}
\hline \multirow[b]{3}{*}{ Variable } & \multicolumn{8}{|c|}{ 5-HTTLPR genotype } & \multirow{3}{*}{$\begin{array}{c}t \text {-test, } d f=60 \\
\text { LL vs. SS/SL }\end{array}$} \\
\hline & \multicolumn{2}{|c|}{$\begin{array}{c}\mathrm{LL} \\
(n=16)\end{array}$} & \multicolumn{2}{|c|}{$\begin{array}{c}\mathrm{SL} \\
(n=33)\end{array}$} & \multicolumn{2}{|c|}{$\begin{array}{c}\text { SS } \\
(n=13)\end{array}$} & \multicolumn{2}{|c|}{$\begin{array}{c}\mathrm{SS} / \mathrm{SL} \\
(n=46)\end{array}$} & \\
\hline & Mean & SD & Mean & SD & Mean & SD & Mean & SD & \\
\hline \multicolumn{10}{|c|}{ Child dependent variables: CBCL } \\
\hline Aggressive Behavior & 12.69 & 7.12 & 9.12 & 6.52 & 6.31 & 4.63 & 8.33 & 6.13 & $-2.35, p<0.05$ \\
\hline Anxious/Depressed & 5.19 & 4.31 & 2.82 & 3.05 & 2.62 & 2.66 & 2.76 & 2.91 & $-2.52, p<0.05$ \\
\hline \multicolumn{10}{|c|}{ Child post hoc variables: CBCL } \\
\hline Total Behavior Problems & 35.19 & 21.63 & 24.52 & 16.16 & 19.23 & 11.28 & 23.02 & 15.01 & $-2.50, p<0.05$ \\
\hline Externalizing & 14.63 & 8.81 & 10.94 & 7.62 & 7.38 & 5.39 & 9.93 & 7.19 & $-2.12, p<0.05$ \\
\hline Delinquent Behavior & 1.94 & 1.95 & 1.82 & 1.53 & 1.08 & 1.19 & 1.61 & 1.47 & $-0.71, p=0.48$ \\
\hline Internalizing & 9.13 & 6.86 & 5.64 & 5.06 & 5.69 & 5.04 & 5.65 & 5.00 & $-2.17, p<0.05$ \\
\hline Withdrawn & 2.00 & 1.75 & 1.70 & 1.96 & 2.00 & 1.96 & 1.78 & 1.94 & $-0.40, p=0.69$ \\
\hline Somatic Complaints & 2.00 & 1.86 & 1.30 & 1.63 & 1.15 & 2.03 & 1.26 & 1.73 & $-1.44, p=0.15$ \\
\hline Social Problems & 3.50 & 2.90 & 1.88 & 1.76 & 1.54 & 1.39 & 1.78 & 1.66 & $-2.90, p<0.05$ \\
\hline Thought Problems & 0.63 & 1.50 & 0.52 & 0.83 & 0.23 & 0.60 & 0.43 & 0.78 & $-0.65, p=0.52$ \\
\hline Attention Problems & 3.88 & 2.60 & 2.91 & 2.63 & 2.69 & 3.43 & 2.85 & 2.84 & $-1.27, p=0.21$ \\
\hline
\end{tabular}

In future studies, examination of other 5-HT and neurochemical measures would be helpful in discerning the risks for alcoholism and related behavioral and affective dysregulation found in COAs. Other child/adolescent studies are also necessary to replicate these findings. That these findings were observed in a medication-free, communityrecruited sample, and in an age range in which regular drinking has not yet begun, suggests that this association may generalize to the overall population.

\section{REFERENCES}

Abecasis GR, Cardon LR, Cookson WO (2000) A general test of association for quantitative traits in nuclear families. Am J Hum Genet 66:279-292.

Achenbach TM (1991) Manual for the Child Behavior Checklist/4-18 and 1991 Profile. University of Vermont Department of Psychiatry, Burlington.

Brown GL, Linnoila MI (1990) CSF serotonin metabolite (5-HIAA) studies in depression, impulsivity, and violence. J Clin Psychiatry 51:3141.

Cloninger CR, Bohman M, Sigvardsson S (1981) Inheritance of alcohol abuse. Cross-fostering analysis of adopted men. Arch Gen Psychiatry 38:861-868.

Coccaro EF, Kavoussi RJ, Sheline YI, Berman ME, Csernansky JG (1997) Impulsive aggression in personality disorder correlates with platelet 5- $\mathrm{HT}_{2 \mathrm{~A}}$ receptor binding. Neuropsychopharmacology 16:211-216.

Cravchik A, Goldman D (2000) Neurochemical individuality: Genetic diversity among human dopamine and serotonin receptors and transporters. Arch Gen Psychiatry 57:1105-1114.

Edenberg HJ, Reynolds J, Koller DL, Begleiter H, Bucholz KK, Conneally PM, Crowe R, Goate A, Hesselbrock V, Li TK, Nurnberger JI Jr, Porjesz B, Reich T, Rice JP, Schuckit M, Tischfield JA, Foroud T (1998) A family-based analysis of whether the functional promoter alleles of the serotonin transporter gene HTT affect the risk for alcohol dependence. Alcohol Clin Exp Res 22:1080-1085.

Ernouf D, Compagnon P, Lothion P, Narcisse G, Benard JY, Daoust M (1993) Platelet 3H 5-HT uptake in descendants from alcoholic patients: A potential risk factor for alcohol dependence. Life Sci 52:989-995.

Feighner J, Robins E, Guze S, Woodruff R, Winokur G, Munoz R (1972) Diagnostic criteria for use in psychiatric research. Arch Gen Psychiatry 26:57-63.

Fils-Aime M, Eckardt M, George D, Brown G, Mefford M, Linnoila M (1996) Early-onset alcoholics have lower CSF 5-HIAA than late-onset alcoholics. Arch Gen Psychiatry 53:211-216.
Fitzgerald HE, Zucker RA, Yang H-Y (1995) Developmental systems theory and alcoholism: Analyzing patterns of variation in high-risk families. Psychol Addict Behav 9:1-15.

Gelernter J, Kranzler H, Coccaro EF, Siever LJ, New AS (1998) Serotonin transporter protein gene polymorphism and personality measures in African American and European American subjects. Am J Psychiatry 155:1332-1338.

Greenberg BD, Li Q, Lucas FR, Hu S, Sirota LA, Benjamin J, Lesch KP, Hamer D, Murphy DL (2000) Association between the serotonin transporter promoter polymorphism and personality traits in a primarily female population sample. Am J Med Genet 96:202-216.

Greenberg BD, Tolliver TJ, Huang SJ, Li Q, Bengel D, Murphy DL (1999) Genetic variation in the serotonin transporter promoter region affects serotonin uptake in human blood platelets. Am J Med Genet 88:83-87.

Hallikainen T, Saito T, Lachman HM, Volavka J, Pohjalainen T, Ryynanen OP, Kauhanen J, Syvalahti E, Hietala J, Tiihonen J (1999) Association between low activity serotonin transporter promoter genotype and early onset alcoholism with habitual impulsive violent behavior. Mol Psychiatry 4:385-388.

Hammoumi S, Payen A, Favre J-D, Balmes J-L, Benard J-Y, Husson M, Ferrand J-P, Martin J-P, Daoust M (1999) Does the short variant of the serotonin transporter linked polymorphic region constitute a marker of alcohol dependence? Alcohol 17:107-112.

Hanna GL, Himle JA, Curtis GC, Koram DQ, Veenstra-VanderWeele J, Leventhal BL, Cook EH Jr (1998) Serotonin transporter and seasonal variation in blood serotonin in families with obsessive-compulsive disorder. Neuropsychopharmacology 18:102-111.

Heinz A, Jones DW, Mazzanti C, Goldman D, Ragan P, Hommer D, Linnoila M, Weinberger DR (2000) A relationship between serotonin transporter genotype and in vivo protein expression and alcohol neurotoxicity. Biol Psychiatry 47:643-649.

Higley JD, Suomi SJ, Linnoila M (1996) A nonhuman primate model of type II alcoholism? Part 2. Diminished social competence and excessive aggression correlates with low cerebrospinal fluid 5-hydroxyindoleacetic acid concentrations. Alcohol Clin Exp Res 20:634-650.

Ishiguro H, Saito T, Akazawa S, Mitushio H, Tada K, Enomoto M, Mifune H, Toru M, Shibuya H, Arinami T (1999) Association between drinkingrelated antisocial behavior and a polymorphism in the serotonin transporter gene in a Japanese population. Alcohol Clin Exp Res 23:12811284.

Johnson BA (2000) Serotonergic agents and alcoholism treatment: Rebirth of the subtype concept-An hypothesis. Alcohol Clin Exp Res 24:1597-1601.

Johnson BA, Roache JD, Javors MA, DiClemente CC, Cloninger CR, Prihoda TJ, Bordnick PS, Ait-Daoud N, Hensler J (2000) Ondansetron for reduction of drinking among biologically predisposed alcoholic patients: A randomized controlled trial. JAMA 284:963-971. 
Jorm AF, Henderson AS, Jacomb PA, Christensen H, Korten AE, Rodgers B, Tan X, Easteal S (1998) An association study of a functional polymorphism of the serotonin transporter gene with personality and psychiatric symptoms. Mol Psychiatry 3:449-451.

Kaufman J, Birmaher B, Perel J, Dahl RE, Stull S, Brent D, Trubnick L, Al-Shabbout M, Ryan ND (1998) Serotonergic functioning in depressed abused children: Clinical and familial correlates. Biol Psychiatry 44:973981.

Knutson B, Wolkowitz OM, Cole SW, Chan T, Moore EA, Johnson RC, Terpstra J, Turner RA, Reus VI (1998) Selective alteration of personality and social behavior by serotonergic intervention. Am J Psychiatry 155:373-379.

Kruesi MJP, Rapoport JL, Hamburger S, Hibbs E, Potter WZ, Lenane M, Brown GL (1990) Cerebrospinal fluid monoamine metabolites, aggression, and impulsivity in disruptive behavior disorders of children and adolescents. Arch Gen Psychiatry 47:419-426.

LeMarquand DG, Benkelfat C, Pihl RO, Palmour RM, Young SN (1999) Behavioral disinhibition induced by tryptophan depletion in nonalcoholic young men with multigenerational family histories of paternal alcoholism. Am J Psychiatry 156:1771-1779.

Lesch K-P, Bengel D, Heils A, Sabol SZ (1996) Association of anxietyrelated traits with a polymorphism in the serotonin transporter gene regulatory region. Science 274:1527-1531.

Lesch K-P, Mossner R (1998) Genetically driven variation in serotonin uptake: Is there a link to affective spectrum, neurodevelopmental, and neurodegenerative disorders? Biol Psychiatry 44:179-192.

Lichtermann D, Hranilovic D, Trixler M, Franke P, Jernej B, Delmo CD, Knapp M, Schwab SG, Maier W, Wildenauer DB (2000) Support for allelic association of a polymorphic site in the promoter region of the serotonin transporter gene with risk for alcohol dependence. Am J Psychiatry 157:2045-2047.

Linnoila M, Virkkunen M, Sheinin M, Nuutila A, Rimon R, Goodwin FK (1983) Low cerebrospinal fluid 5-hydroxyindoleacetic acid concentration differentiates impulsive from non-impulsive violent behavior. Life Sci 33:2609-2614.

Little KY, McLaughlin DP, Zhang L, Livermore CS, Dalack GW, McFinton PR, DelProposto ZS, Hill E, Cassin BJ, Watson SJ, Cook EH (1998) Cocaine, ethanol, and genotype effects on human midbrain serotonin transporter binding sites and mRNA levels. Am J Psychiatry 155:207213.

Lucki I (1998) The spectrum of behaviors influenced by serotonin. Biol Psychiatry 44:151-162.

Mann JJ, Huang YY, Underwood MD, Kassir SA, Oppenheim S, Kelly TM, Dwork AJ, Arango V (2000) A serotonin transporter gene promoter polymorphism (5-HTTLPR) and prefrontal cortical binding in major depression and suicide. Arch Gen Psychiatry 57:729-738.

Manuck SB, Flory JD, McCaffery JM, Matthews KA, Mann JJ, Muldoon MF (1998) Aggression, impulsivity, and central nervous system serotonergic responsivity in a nonpatient sample. Neuropsychopharmacology 19:287-299.

Mazzanti CM, Lappalainen J, Long JC, Bengel D, Naukkarinen H, Eggert M, Virkkunen M, Linnoila M, Goldman D (1998) Role of the serotonin transporter promoter polymorphism in anxiety-related traits. Arch Gen Psychiatry 55:936-940.

Mehlman PT, Higley JD, Faucher I, Lilly AA, Taub DM, Vickers J, Suomi SJ, Linnoila M (1995) Correlations of CSF 5-HIAA concentration with sociality and the timing of emigration in free-ranging primates. Am J Psychiatry 152:907-913.

Nobile M, Begni B, Giorda R, Frigerio A, Marino C, Molteni M, Ferrarese C, Battaglia M (1999) Effects of serotonin transporter promoter genotype on platelet serotonin transporter functionality in depressed children and adolescents. J Am Acad Child Adolesc Psychiatry 38: $1396-1402$.

Ohara K, Nagai M, Tsukamoto T, Tani K, Suzuki Y, Ohara K (1998) Functional polymorphism in the serotonin transporter promoter at the SLC6A4 locus and mood disorders. Biol Psychiatry 44:550-554.
Pfeffer CR, McBride PA, Anderson GM, Kakuma T, Fensterheim L, Khait V (1998) Peripheral serotonin measures in prepubertal psychiatric inpatients and normal children: Associations with suicidal behavior and its risk factors. Biol Psychiatry 44:568-577.

Poon E, Ellis DA, Fitzgerald HE, Zucker RA (2000) Intellectual, cognitive, and academic performance among sons of alcoholics during the early school years: Differences related to subtypes of familial alcoholism. Alcohol Clin Exp Res 24:1020-1027.

Pritchard JK, Stephens M, Rosenberg NA, Donnelly P (2000) Association mapping in structured populations. Am J Hum Genet 67:170-181.

Raleigh MJ, Brammer GL, McGuire MT (1983) Male dominance, serotonergic systems, and the behavioral and physiological effects of drugs in vervet monkeys (Cercopithecus aethiops sabaeus). Prog Clin Biol Res 131:185-197.

Raleigh MJ, Brammer GL, McGuire MT, Yuwiler A (1985) Dominant social status facilitates the behavioral effects of serotonergic agonists. Brain Res 348:274-282.

Rausch JL, Monteiro MG, Schuckit MA (1991) Platelet serotonin uptake in men with family histories of alcoholism. Neuropsychopharmacology 4:83-86.

Sander T, Harms H, Dufeu P, Kuhn S, Hoehe M, Lesch KP, Rommelspacher H, Schmidt LG (1998) Serotonin transporter gene variants in alcohol-dependent subjects with dissocial personality disorder. Biol Psychiatry 43:908-912.

Sander T, Harms H, Lesch KP, Dufeu P, Kuhn S, Hoehe M, Rommelspacher H, Schmidt LG (1997) Association analysis of a regulatory variation of the serotonin transporter gene with severe alcohol dependence. Alcohol Clin Exp Res 21:1356-1359.

Schuckit MA, Mazzanti C, Smith TL, Ahmed U, Radel M, Iwata N, Goldman D (1999) Selective genotyping for the role of $5-\mathrm{HT} 2_{\mathrm{A}}$, $5-\mathrm{HT} 2_{\mathrm{C}}$, and GABA alpha 6 receptors and the serotonin transporter in the level of response to alcohol: A pilot study. Biol Psychiatry 45:647651.

Sher KJ (1991) Children of Alcoholics: A Critical Appraisal of Theory and Research. University of Chicago Press, Chicago.

Sher KJ (1997) Psychological characteristics of children of alcoholics. Alcohol Health Res World 21:247-254.

Stevens G, Featherman DL (1981) A revised socioeconomic index of occupational status. Soc Sci Res 10:364-395.

Stoff DM, Vitiello B (1996) Role of serotonin in aggression of children and adolescents: Biochemical and pharmacological studies, in Aggression and Violence: Genetic, Neurobiological, and Biosocial Perspectives (Stoff DM, Cairns RB eds), pp 101-123. Erlbaum Associates, Mahwah, NJ.

Stoltenberg SF, Burmeister M (2000) Recent progress in psychiatric genetics-Some hope but no hype. Hum Mol Genet 9:927-935.

Turker T, Sodmann R, Goebel U, Jatzke S, Knapp M, Lesch KP, Schuster R, Schutz H, Weiler G, Stober G (1998) High ethanol tolerance in young adults is associated with the low-activity variant of the promoter of the human serotonin transporter gene. Neurosci Lett 248:147-150.

Twitchell GR, Hanna GL, Cook EH, Fitzgerald HE, Little KY, Zucker RA (1998) Overt behavior problems and serotonergic function in middle childhood among male and female offspring of alcoholic fathers. Alcohol Clin Exp Res 22:1340-1348.

Twitchell GR, Hanna GL, Cook EH, Fitzgerald HE, Zucker RA (2000) Serotonergic function, behavioral disinhibition, and negative affect in children of alcoholics: The moderating effects of puberty. Alcohol Clin Exp Res 24:972-979.

Virkkunen M, DeJong J, Bartko J, Linnoila M (1989) Psychobiological concomitants of history of sucide attempts among violent offenders and impulsive fire setters. Arch Gen Psychiatry 46:604-606.

Virkkunen M, Eggert M, Rawlings R, Linnoila M (1996) A prospective follow-up study of alcoholic violent offenders and fire setters. Arch Gen Psychiatry 53:523-529. 
Wong MM, Zucker RA, Fitzgerald HE, Puttler LI (1999) Heterogeneity of risk aggregation for alcohol problems between early and middle childhood: Nesting structure variations. Dev Psychopathol 11:727-744.

Zucker RA (1987) The four alcoholisms: A developmental account of the etiologic process, in Nebraska Symposium on Motivation: Alcohol and Addictive Behaviors (Rivers PC ed), pp 27-83. University of Nebraska Press, Lincoln.
Zucker RA, Ellis DA, Bingham CR, Fitzgerald HE (1996) The development of alcoholic subtypes: Risk variation among alcoholic families during the early childhood years. Alcohol Health Res World 20:46-54.

Zucker RA, Ellis DA, Fitzgerald HE, Bingham CR, Sanford DP (1997) Other evidence for at least two alcoholisms, II: Life course variation in antisociality and heterogeneity of alcoholic outcome. Dev Psychopathol 8:831-848. 